Pamiętnik Literacki 2019, 2, s. 155-170

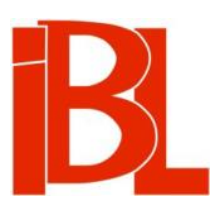

\title{
Emancypacyjny projekt Malwiny Meyersonowej. Wokół recepcji dwóch powieści
}

Anna Jeziorkowska-Polakowska 
Pamiętnik Literacki CX, 2019, z. 2, PL ISSN 0031-0514

DOI: $10.18318 / \mathrm{pl} .2019 .2 .9$

ANNA JEZIORKOWSKA-POLAKOWSKA Katolicki Uniwersytet Lubelski Jana Pawła II

\section{EMANCYPACYJNY PROJEKT MALWINY MEYERSONOWEJ WOKÓŁ RECEPCJI DWÓCH POWIEŚCI}

Niniejszy artykuł ma na celu przywrócenie pamięci o twórczości Malwiny Meyersonowej ${ }^{1}$, pisarki, tłumaczki, działaczki społecznej, pierwszej lubelskiej Żydówki publikującej po polsku. Jej dorobek włączony zostaje w nurt literatury wywodzącej się $z$ ruchu oświeceniowego Żydów (Haskali), wiąże się z ideą emancypacji, $z$ dążeniem do wyjścia $z$ wielowiekowej izolacji i $z$ uzyskaniem pełni praw obywatelskich. W ostatnich latach obserwujemy ogromne zainteresowanie tzw. kwestią żydowska, powstało wiele tekstów dotyczących różnych wymiarów asymilacji i przemian ważnych dla XIX-wiecznej społeczności żydowskiej w Polsce ${ }^{2}$.

Przywoływanie postaci i twórczości Meyersonowej, poza wskazaniami czysto historycznymi, może wydawać się mało zasadne, zwłaszcza że jej teksty są zupełnie niedostępne dla współczesnego czytelnika, nie wznawiano ich bowiem od prawie półtora wieku ${ }^{3}$. Henryk Gawarecki w „Kurierze Lubelskim” z roku 1968, w artyku-

1 Malwina (Małka) M e ye r s o n ow a (ur. 3 III 1839 w Lublinie, zm. 13 I 1922 tamże) - była córką Ezryela Horowicza i Frymety z Jakubów, żoną Bernarda (Berka) Meyersona oraz matką poetki Franciszki Arnsztajnowej i filozofa Emila (Ezryela) Meyersona.

2 Tematy poruszane w powieściach Meyersonowej znalazły współcześnie najpełniejsze odzwierciedlenie w pracach: Kwestia żydowska w XIX wieku. Spory o tożsamość Polaków. Praca zbiorowa. Red. G. Borkowska, M. Rudkows ka. Warszawa 2004. - A. J a g o d ziń s ka, Czy historia ma płeć? Gender, źródła i akulturacja Żydów w Królestwie Polskim. W zb.: Nieme dusze? Kobiety $w$ kulturze jidysz. Red. J. Li s e k. Wrocław 2010. - Jewish writing in Poland. Ed. M. A d a m c zy k - Garbowska, E. Prokop-Janiec, A. Polonsky, S. J. Żurek. Oxford 2016. O problemie asymilacji możemy przeczytać ponadto w takich publikacjach: Ortodoksja, emancypacja, asymilacja. Studia z dziejów ludności żydowskiej na ziemiach polskich $w$ okresie rozbiorów. Red. K. Zi elińs ki, M. Ad a m c zy k - G a r b ow s k a. Lublin 2003. - Wokół akulturacji i asymilacji Żydów na ziemiach polskich. Red. K. Zi el i ń s ki. Lublin 2010. - Polish and Hebrew Literature and National Identity. Ed. A. Molis a k, S. Ronen. Warsaw 2010. Zagadnienie stosunku twórców okresu pozytywizmu i późniejszych do kwestii żydowskiej poruszyli zaś m.in.: A. Fried ri c h, Bolesław Prus wobec kwestii żydowskiej. W zb.: Bolesław Prus: pisarz, publicysta, myśliciel. Red. M. W oźniakiewicz-Dziad os z, S. Fita. Lublin 2003. - S. Kar pow i c z-Słow ik ow s ka, O mniejszościach etnicznych $w$ publicystyce Bolesława Prusa. „Pamiętnik Literacki” 2009, z. 4. M. Pi ekara, Kwestia żydowska $w$ publicystyce Elizy Orzeszkowej. Katowice 2013. Ocena projektu emancypacyjnego Meyersonowej została zawarta np. w pracy B. U mińs ki ej Postać z cieniem. Portrety Żydówek $w$ polskiej literaturze od końca XIX wieku do 1939 roku (Warszawa 2001) oraz w zbiorach: Żydzi i judaizm we wspótczesnych badaniach polskich (Red. K. Pilarczyk. T. 5. Kraków 2010) i Literatura polsko-żydowska. Studia i szkice (Red. E. Proko p-J a ni e c, S. J. Żurek. Kraków 2011).

$3 \quad$ O pisarce wzmiankuje Leksykon żydowski z 1930 r. oraz Bibliografia polska K. Es tre i c h e r a 
le o znanej lubelskiej rodzinie Meyersonów, podaje następujące informacje na temat dzieł pisarki:

Pani Malwina miała uzdolnienia literackie i w 1868 roku wystapiła z powieścią Dawid, która wcześniej drukowana była w tygodniku „Izraelita”. Był to - jak czytamy w podtytule - Obrazek z życia tegoczesnych Żydów, niewielka książeczka, licząca 132 strony. Drugą i ostatnią, jak się zdaje, powieścią Meyersonowej była wydana (tak jak i poprzednia w Warszawie) w 1878 r. pt. Z ciasnej sfery. Powieść podług podań i papierów familijnych, obszerniejsza, bo licząca ponad 200 stron.

W obu powieściach poruszała problemy współczesnego życia ludności żydowskiej i w tym zakresie była prekursorką powieści Elizy Orzeszkowej o tej samej tematyce.

Dziwne fatum zaciążyło nad twórczością Meyersonowej - gdy jeszcze w XIX w. książki jej znajdowały się w katalogach wszystkich czytelni lubelskich, obecnie nie ma ich w żadnej z publicznych bibliotek naszego miasta ${ }^{4}$.

Konrad Bielski z kolei w swoich lubelskich wspomnieniach mówi, że Meyersonowa (błędnie nazwał ją Karolina) „była powieściopisarką czynną w połowie ubiegłego wieku. Nie spotkałem się z jej utworami. Zginęły w cieniu Elizy Orzeszkowej i tylu innych swietnych pisarzy tamtych lat” ${ }^{2}$. W podobnym tonie o autorce Dawida wypowiadał się Robert Kuwałek:

Malwina Meyersohn była pierwszą lubelską Żydówką, która pisała i wydawała swoje utwory po polsku. Jej pozytywistyczna powieść, zatytułowana $Z$ ciasnej sfery, drukowana była w odcinkach na łamach „Kuriera Lubelskiego” w latach siedemdziesiątych XIX wieku. Może nie była to twórczość najwyższych lotów i przyćmiewało ją w tym czasie pisarstwo Orzeszkowej, ale jak na prowincjonalny Lublin było to wielkie wydarzenie literackie. Oczywiście, wiodącym tematem pisarstwa Meyersohnowej była asymilacja i potrzeba oświaty wśród ortodoksyjnych mas żydowskich. Nic też dziwnego, że trafiła też na łamy warszawskiego „Izraelity”, głównego organu asymilatorów w Królestwie Polskim ${ }^{6}$.

Współczesne opinie na temat dokonań Meyersonowej z jednej strony wskazują na ich niewielką wartość artystyczną i wynikającą $z$ tego faktu całkowitą niepamięć, natomiast $z$ drugiej - akcentują związki łączące twórczość lublinianki z pisarstwem

(T. 6. Wyd. 2. Kraków 1967). Współczesny słownik Historia i kultura Żydów polskich (Warszawa 2000, s. 189), autorstwa A. Całej, H. Węgrzynek i G. Zalewskiej, informuje: „pierwsza pisarką w historii polskich Żydów była M. Meyersonowa, autorka opowiadania Dawid (1878) [błąd w dacie, właściwy rok to 1868 - A. J.-P.] i powieści $Z$ ciasnej sfery (1878)”. Dzieła Meyersonowej stanowią rzadkość nawet w najlepszych i największych bibliotekach. W Bibliotece Ossolineum obok kart katalogowych Dawida i utworu $Z$ ciasnej sfery widnieje karta powieści L. von Franço is Ostatnia z Rekenburgów (Warszawa 1877), którą tłumaczyła M. M eyersonowa.

4 H. G aw a r e cki, Dawny Lublin (II). „Kurier Lubelski” 1968, nr 35, s. 3. Przedruk: G a w a r e c ki, O dawnym Lublinie, s. 168-169.

Henryk G aw a r e cki (1912-1989) - polski historyk sztuki, bibliofil, prezes Lubelskiego Oddziału PTK-PTTK, członek honorowy Towarzystwa Przyjaciół Sztuk Pięknych w Lublinie, autor wielu opracowań i artykułów dotyczących Lublina i Lubelszczyzny, m.in. O dawnym Lublinie. Szkice z przeszłości miasta (Wyd. 2, uzup. i przejrz. Lublin 1986).

$5 \quad$ K. Bielski, Most nad czasem. Lublin 1963, s. 236.

Konrad Bielski (1902-1970) - pseud. Ptak Tomasz, Ziemie Sergiusz, poeta, prozaik, z W. Gralewskim i J. Arnsztajnem był współautorem „Szopek Lubelskich”. Wydał m.in. poemat Trzydziesty ósmy równoleżnik (Warszawa 1954), Siedem dawnych wierszy (Lublin 1960), swoje wspomnienia lubelskie spisał w cytowanej tu książce Most nad czasem, a kazimierskie - w Spotkaniach z Kazimierzem (Lublin 1965) i w Tajemnicy kawiarni „U Aktorów” (Lublin 1970).

6 R. Kuw ał e k, Czy Lublin miał żydowskie elity? „Scriptores” 2003, nr 27, s. 101. 
Orzeszkowej ${ }^{7}$. Bardzo krytyczny w ocenach Robert Stiller używa sformułowania, że teksty Meyersonowej „wywarły prekursorski wpływ na żydowskie powieści Elizy Orzeszkowej”; cytowany już Gawarecki zastanawia się, co było przyczyną tego, że „działalność literacka Malwiny Meyersonowej, zapowiadająca się tak interesująco, została całkowicie zapomniana”, i dlaczego „Nazwiska jej nie zanotowała żadna encyklopedia polska, a nawet monograficzne opracowanie: Lublin w życiu i twórczości pisarzy polskich Augusta Grychowskiego [...]"9. We współczesnym dyskursie literaturoznawczym artykuły dotyczące dokonań Meyersonowej pojawiają się rzadko i przedstawiaja ją raczej jako autorkę „powieści zideologizowanej oraz tendencyjnej” 10 lub „opierającej się na modelu literatury tendencyjnej” ${ }^{11}$ albo próbują pokazać szczególna jedność życia i twórczości pisarki - pracy na rzecz kształtowania Polaków wyznania mojżeszowego ${ }^{12}$.

Meyersonowa to niewątpliwie wyjątkowa postać w XIX-wiecznym Lublinie, swoją przynależność do kręgu osób aktywnych tego miasta rozumiała jako swoisty obowiazek obywatelski. Lokalna prasa pełna jest informacji o zaangażowaniu społecznym małżeństwa Meyersonów: wspieraniu wszelkich inicjatyw miejskich, pomocy chorym, ubogim i potrzebującym ${ }^{13}$. Działalność ta znajdowała uznanie także w czasopismach ogólnopolskich. W pochodzącej z Lublina korespondencji zamieszczonej w „Izraelicie” ( $z$ dnia 16 IX 1866), prezentującej trudną sytuację materialną ochronki dla dziewcząt izraelskich w Lublinie, czytamy:

Z całego zastępu Nauczycielek i Opiekunek pozostała tylko zacna i światła pani Mejersohn, która od czasu do czasu odwiedzi i hojną ofiarą wesprze Ochronkę ${ }^{14}$.

7 Problematyka żydowska pojawia się w kilku utworach E. Orzeszkowej (Mirtala, Eli Makower, Meir Ezofowicz, Daj kwiatek, Gedali, Silny Samson, Ogniwa, Rotszyldówna), jest też głównym tematem obu wymienionych powieści Meyersonowej.

8 R. R. S till e r, Żydowskie abecadło twórców literatury polskiej, czyli od A do Żet z prawa na lewo. Kraków 2011, s. 77. Oto cały cytat $z$ tej samej stronicy: „Malwina Meyersonowa (właściwie Małka, 1839-1921) uchodziła zwłaszcza w rodzinnym Lublinie za talent powieściopisarski. Jej dorobek zakończył się na dwóch krótkich powieściach obyczajowych: Dawid, 1868 i $Z$ ciasnej sfery, 1878, wówczas bardzo poczytnych, później do tego stopnia zapomnianych, że ich egzemplarze stały się prawie nieosiagalne. Utwory te wywarły prekursorski wpływ na żydowskie powieści Elizy Orzeszkowej. Niestety, wartość ich trzeba określić jako wyłącznie historyczną i dokumentalną, bo ani koncepcja czy konstrukcja literacka, ani język, styl i sposób narracji nie wykazują cech artystycznych”. Opinia Stillera na temat wpływu twórczości Meyersonowej na pisarstwo Orzeszkowej wydaje się nieuzasadniona, nie jest bowiem poparta żadnymi dowodami.

G a w a r e cki, Dawny Lublin (II), s. 3.

10 D. Kalin ow s ki, Ku świattu... Twórczość literacka Malwiny Meyersonowej. W zb.: Żydzi Wschodniej Polski. Seria 3: Kobieta żydowska. Red. nauk. A. J a n i cka, J. Ław s k i, B. Ole c h. Białystok 2015, s. 181-182.

11 A. Arczyń ska, Twórczość Malwiny Meyersonowej. „Prace Literackie” 2002, s. 78.

12 Zob. A. J e zi or k ow s k a - Pol a k ow s ka: „Ciemne swoje rzesze wiodła ku świattości”. Twórczość literacka i działalność społeczna Malwiny Meyersonowej. W zb.: Żydzi Wschodniej Polski; „Bracia! Ilu nas jest, podajmy sobie ręce, a zmurszała warownia runie bezpowrotnie...” - postulatywny charakter twórczości Malwiny Meyersonowej. W zb.: Wymiary tolerancji w literaturze lat 1864-1914. Red. M. Kłosińska, A. Kowalczyk, M. Leśniewska, I. Poniatowska, A. Wietecha. Warszawa 2017.

14 J. Gold s chmidt, Korespondencja. „Izraelita” 1866, nr 24, z 28 IX, s. 206.

„Izraelita” - żydowski tygodnik w języku polskim, wydawany w Warszawie w latach 1866-1915. 
We wspomnieniu zamieszczonym w miesięczniku „Rozwaga” po śmierci pisarki w 1922 roku Róża Centnerszwerowa w najbardziej chyba wymowny sposób dokonała podsumowania jej ponad 80-letniego życia:

Budzenie ducha polskości i uczuć obywatelskich, zrazu w gronie rówieśnic i rówieśników, potem wśród coraz szerszych kół społeczeństwa żydowskiego, zjednywanie zwolenników tej sprawy spośród sfer chrześcijańskich najinteligentniejszych i najszlachetniej ideowych - stało się zadaniem życia Meyersonowej. Ideałowi temu poświęciła ona zarówno całą swoją działalność społeczną, jak i duży talent literacki ${ }^{15}$.

Choć dorobek literacki Meyersonowej nie jest imponujący (dwie powieści autorskie i dwa przekłady z literatury niemieckiej), to dokonania te - z perspektywy jej ogromnego zaangażowania $\mathrm{w}$ pracę na rzecz szerzenia oświaty i działalności patriotycznej - nabieraja dodatkowego znaczenia. Tak naprawdę nie sposób oddzielić życia prywatnego od społecznego i artystycznego, przenikały się one, uzupełniały nawzajem i stanowiły jedno. Przywoływaniu pamięci o Meyersonowej posłużą artykuły, komentarze, recenzje i korespondencje z ówczesnej prasy. Pokazują one bowiem, że jej teksty były poczytne i ważne.

Obie powieści Meyersonowej wydrukowano najpierw w „Izraelicie”. Można chyba postawić tezę, że $\mathrm{z}$ tym tygodnikiem autorka była dość mocno związana. Potwierdza to nawet zestawienie osób współpracujących $z$ redakcją, zamieszczone z okazji 25-lecia pisma, w numerze 18 z 1891 roku. Na 58 wymienionych nazwisk tylko cztery należą do kobiet: Marii Konopnickiej, Malwiny Meyersonowej, Elizy Orzeszkowej i Eleonory Pechkrantz ${ }^{16}$. Jak podają twórcy monografii „Izraelita” 1866-1915. Wybór źródet, lista stanowi dobry wgląd w skład redakcji i środowisk $\mathrm{z}$ nią związanych ${ }^{17}$. Podkreślają też znikomą liczbę kobiet i chrześcijan publikujacych w tym tygodniku, a także fakt, że Orzeszkowa i Konopnicka nie były współpracowniczkami „Izraelity”, przedrukowywano w piśmie jedynie ich teksty o tematyce żydowskiej. Agnieszka Jagodzińska i Marcin Wodziński nadmieniają:

Dwie kobiety rzeczywiście współpracujące z tygodnikiem to Eleonora Pechkrantz, zamożna warszawianka, zaangażowana m.in. w pomoc najuboższym dzieciom, która przysyłała korespondencję $z$ Wiednia, oraz Malwina Meyersonowa z Lublina (1839-1922), autorka m.in. opublikowanych w „Izraelicie” powieści historycznej Z ciasnej sfery i powieści obyczajowej Dawid. Obrazek z życia Żydów naszych ${ }^{18}$.

Pierwszy utwór pisarki, przywoływany już tu Dawid, drukowany był od grudnia 1867 do połowy 1868 roku $^{19}$. W numerze 33 z 1868 roku pojawiła się taka oto informacja:

R. C e n t n e r s zw e r ow a, ZŻałobnej karty. Malwina Meyersonowa (1839-1922). „Rozwaga” 1922, nr 1, s. 23.

„Rozwaga” - miesięcznik społeczno-literacki wychodzacy w latach 1915-1928 w Warszawie. Wydawcą i redaktorem był Henryk Nusbaum, od 1922 r. - Stefan Lubliner. Współtwórcy: „Zjednoczenie" - Organizacja Polskiej Młodzieży Akademickiej Pochodzenia Żydowskiego, Koło Patriotów Polskich Wyznania Mojżeszowego, Związek Akademickiej Młodzieży Zjednoczeniowej. Rada Naczelna. Zjednoczenie - Organizacja Polskiej Młodzieży Pochodzenia Żydowskiego. Środowisko Warszawskie. „Izraelita” 1891, nr 18, z 26 IV, s. 176.

17 „Izraelita” 1866-1915. Wybór źródet. Oprac. A. Ja go dziń s ka, M. W o d ziń s ki. Kraków-Budapeszt 2015, s. 32-33.

18 Ibidem, s. 33.

19 Powieść Dawid. Obrazek z życia Żydów tegoczesnych [...] była drukowana od numeru 24 (z 13 XII 
Nakładem S. Silberszteina wyszła powiastka oryginalna pt. Dawid, obrazek z życia Żydów tegoczesnych, przez p. Malwinę Meyerson (odbitek ze szpalt „Izraelity”). - Nabyć można u wydawcy, ulica Nalewki nr 2250, oraz w redakcji „Izraelity”. - Cena egzemplarza kop. $30^{20}$.

Szukając wiadomości na temat tej publikacji w ówczesnej lubelskiej prasie lokalnej, natrafiłam na następujący anons:

P. Samuel Silbersztejn przesłał do Towarzystwa Dobroczynności Warszawskiej 56 exemplarzy wydanej przez siebie powieści Dawid przez p. Malwinę Meyersohn na rzecz ochron warszawskich ${ }^{21}$.

To najlepszy dowód na to, jak postulaty i idee propagowane przez pisarkę za pomocą słowa drukowanego można wprowadzać w czyn. W przedmowie do powieści, autorstwa Samuela Silbersztejna, wydawcy Dawida, czytamy:

Obrazek ten, tak wiernie i udatnie stosunki izraelskiego społeczeństwa w Królestwie Polskim zamieszkałego malujący, który tak dla swej tendencji, jako i wybornego obrobienia zyskał sobie u czytającej publiczności powszechna pochwałę, zdawał mi się być godnym szerszego rozpowszechnienia i trwalszego w literaturze bytu, aniżeli karty czasopisma zapewnić by mu zdołały. [MD III-IV] ${ }^{22}$

Dawid Rothman, tytułowy bohater, zgodnie $z$ wolą ojca miał zostać mełamedem w chederze, dlatego od wczesnych lat dziecięcych studiował Talmud i Torę. Nie szło to jednak w parze $z$ jego marzeniami i zdolnościami, ponieważ był utalentowany muzycznie i pragnął poświęcić się tej dziedzinie sztuki. Przypadek sprawił, że spotkał doktora Hellera, dzięki któremu został muzykiem i kompozytorem. To właśnie Heller, przedstawiciel nowej inteligencji żydowskiej, wprowadził w czyn pozytywistyczne hasła szerzenia oświaty wśród biednej młodzieży żydowskiej pochodzącej z tradycyjnych, ortodoksyjnych kręgów. Meyersonowa tak charakteryzuje doktora:

był jednym $z$ tych często jeszcze u nas napotykanych ludzi, którzy w młodości swojej, siłą woli i bogactwem wrodzonych zdolności, przełamać zdołali zapory, jakie im przesądy ojców, brak sposobności, a później uprzedzenie współuczących się na drodze nauki stawiały. Jednym z tej licznej u nas falangi wojowników ducha, stawających do głuchej walki światła z ciemnością! Walki ciężkiej, a często i niebezpiecznej. [MD 37]

Heller, który, jak czytamy, „Podniósłszy się własna pracą, [...] nie przestawał patrzeć na dół z myślą podźwignięcia braci żydowskich, do których zawsze jeszcze sercem należał [...]” (MD 39), bardzo stanowczo upominał Dawida:

Jesteś Żydem! Strzeż się, abyś nie pogardzał tymi ubogimi braćmi w Izraelu, którzy z wysokości

1867). Drugi i trzeci rozdział ukazały się jeszcze w tym samym roku (numery 25-26), piętnaście dalszych już w roku kolejnym, 1868 (numery: 1-4, 6-14, 16-17). „Izraelita” 1868, nr 33, z 21 VIII, s. 272.

Rozmaitości. „Kurier Lubelski” 1869, nr 48, z 19 VI, s. 2.

Skrótem MD odsyłam do: M. M ey e r s o h n, Dawid. Obrazek z życia Żydów tegoczesnych [...]. Warszawa 1868. Na stronie: http://www.rcin.org.pl/Content/9633/WA248_21142_F-22-232_meyersohn-dawid-o.pdf (data dostępu: 7 VII 2017). Ponadto w artykule stosuje jeszcze takie skróty: $\mathrm{K}=\mathrm{S}$. K. [S. Krzemiński], Przeglad piśmienniczy. „Bluszcz” 1878, nr 45, z 6 XI. - MZ = M. M e y e r s o n ow a, $Z$ ciasnej sfery. Powieść. Podług podań i papierów familijnych. Warszawa 1878. Na stronie: http://www.rcin.org.pl/dlibra/docmetadata?id=13655\&from=publication (data dostępu: 7 VII 2017). - S = L. Sow iń s ki, Nowości literackie. „Kłosy” 1878, nr 681, z 18 VII. $\mathrm{Sz}=$ L. S. W. [L. L. S z c z e r b o w i c z - W i e c zó r], Przegląd piśmienniczy. „Tygodnik Ilustrowany” 1879, nr 196, z 27 IX. Liczby po skrótach oznaczają stronice. 
innego większego świata wydawać ci się kiedyś mogą mało znaczącymi robaczkami wśród wielkiego mrowiska narodów. [MD 51]

Nauka tolerancji i szacunku była nie mniej ważna niż wiedza i doskonalenie umiejętności muzycznych. Poczucie przynależności do społeczeństwa żydowskiego i odpowiedzialności za jego rozwój cechowały wszystkie działania Hellera, który tak zwracał się do Dawida: „Kochaj ich [tj. Żydów] sercem i nie zapominaj, że każdy z nas w miarę sił znosić powinien cegiełkę do wielkiej budowy oświaty naszego ludu" (MD 52).

Edukacja, ciagłe doskonalenie siebie, empatia i zrozumienie sa potrzebne do zbudowania tolerancji, która obejmuje nie tylko ludzi z najbliższego otoczenia, ale całe społeczeństwo. Meyersonowa daje wskazówki, co trzeba czynić, aby tak się stało:

zamiast uskarżać, raczej litować się potrzeba nad ludźmi, którzy - czy to przez wrodzoną nieudolność, czy też przez brak wychowania i przykładu - nie mogą brać udziału w szczęściu, wynikającym z czystego uczucia, ze światłej miłości dla Stwórcy i braci swoich, z obejmowania sercem i rozumem nieprzeliczonych zasobów stworzenia, również wielkich w żywej duszy człowieka, jak w tysiącznych ogniwach nieożywionej natury. [MD 106-107]

Autorka postuluje też, aby pracować nad sumiennym wywiąywaniem się z powinności, ale także nad „rozwinięciem w sobie i w bliźnich swoich wszystkich sił duszy [...]”; każdy dzień ma nas przybliżać „o krok jeden do wielkiego celu wspólnej naszej wędrówki, do doskonałości na ziemi” (MD 107). Taka praca u podstaw, szerzenie oświaty, emancypacja kobiet muszą przynieść zamierzone efekty. I choć, jak zauważają Dawid i Heller, wracając po latach do rodzinnego miasteczka, „odmiana w gruncie rzeczy nie jest tak wielką [...]" (MD 131), to jednak można cieszyć się z tego, co się udało zmienić i poprawić. Wolno też mieć nadzieję, że kolejne reformy nastapią, taka jest bowiem według bohaterów powieści natura rzeczy, „czas bez naszej pomocy reszty dokona" (MD 131).

Jak wynika $z$ analizy prasy tamtej epoki, Dawid nie zajmował zbytnio krytyków czy badaczy, prawdopodobnie dlatego, iż - o czym napisała Centnerszwerowa w „Rozwadze” - był to „pełen zapału utwór młociany [młodociany?] [...]”23.

Druga powieść, której już do juweniliów zaliczyć raczej nie można, gdyż autorka miała w momencie jej opublikowania prawie 40 lat, nosi tytuł $Z$ ciasnej sfery. Drukowano ten utwór w „Izraelicie” od października 1877 do kwietnia $1878^{24}$, w tym też roku ukazała się jego wersja książkowa. W numerze 40 z 1877 roku czytamy:

Zwracamy uwagę czytelników naszych na interesującą powieść $Z$ ciasnej sfery znanej autorki, pani Malwiny Meyersonowej, której druk z dzisiejszym numerem rozpoczynamy25.

Informacja $z$ tym związana pojawiła się także w dzienniku miejscowym, „Gazeta Lubelska” z 24 X na pierwszej stronie podała anons: „P. Malwina Meyersonowa

Powieść $Z$ ciasnej sfery publikowana była od numeru 40 (z 19 X 1877) do numeru 50 (z 28 XII 1877). Kolejne rozdziały wydrukowane zostały już w roku następnym, od numeru 1 (z 4 I 1878) do numeru 16 (z 17 IV 1878). 
rozpoczęła w "Izraelicie» druk powieści pt. $Z$ ciasnej sfery"26. Tematem głównym książki jest proces modernizacji społeczności żydowskiej. Akcja toczy się na przełomie XVIII i XIX wieku i obejmuje ponad 20 lat. Znaczenie tytułu próbował objaśnić - chyba jako pierwszy - Leonard Sowiński w tygodniku „Kłosy” już w roku 1878, a więc wkrótce po opublikowaniu powieści:

„Ciasna sfera” - to niedawny, a może jeszcze i dzisiejszy świat izraelski w jego przeważnej części, świat małostek, form czczych i bezdusznych, na budowę którego złożyły się wieki całe przymusowego odosobnienia od reszty ziomków, usunięcia od wielkich spraw współobywateli i kraju - to ograniczone koło potrzeb i interesów kastowych i wyznaniowych. Wszelka wola dzielniejsza, wszelkie gorętsze uczucie doznaje obezwładniających wpływów tej sfery. [S 42]

Trochę inaczej tłumaczył tytuł autor Przegladu piśmienniczego w „Bluszczu”, o inicjałach S. K. (najprawdopodobniej chodzi o Stanisława Krzemińskiego), dostrzegając w nim raczej funkcję energetyzująca, mobilizująca „ciasnej sfery” niż tylko ograniczająca, hamującą czy wręcz obezwładniająca

Tytuł niniejszej powieści to hasło wszelkiego rozwoju i postępu. Czy to idzie o jednostkę, która przemknąć się ma tylko przez ziemię i zniknać, czy o wielkie gromady ludzkie, które życie swoje mierzą wiekami - wszędzie, w trudzie każdym, w walce każdej, na sztandarze każdym, spotykamy to hasło: „Z ciasnej sfery!” Chęć rozszerzenia sfery, w której się żyje, jest istotną matką postępu i dopóki ona duchem nie owładnie, dopóty duch rozwoju rzeczywistego nie zazna: może tylko przyjmować pewne nawyknienia, oswajać się z pewnymi kształtami życia, ale prawdziwie, tj. od wewnątrz, rozwijać się nie zdoła. [K 356-357]

I jeszcze jedna próba zdefiniowania pojęcia, które niewątpliwie zelektryzowało grono krytyków literackich. Tym razem autora Przegladu piśmienniczego, zamieszczonego w 196 numerze „Tygodnika Ilustrowanego” z 1879 roku, podpisanego inicjałami L. S. W. (chodzi chyba o Ludomira Ludwika Szczerbowicza-Wieczora ${ }^{27}$ ), który „ciasną sferę” tłumaczy jako sferę życia żydowskiego, „owianego duchem ścisłej ortodoksji talmudycznej, przenikającej we wszystkie objawy życiowe, regulującej wszystkie nie tylko czyny, ale nawet słowa i myśli prawowiernych Żydów" (Sz 197). Stąd pochodzi - według recenzenta - wyjątkowa odrębność świata żydowskiego, który, tworząc spójna całość, pozostaje zupełnie obojętny na specyfikę i zmiany w kraju zamieszkiwanym przez Żydów. Szczerbowicz-Wieczór ma poważne wątpliwości, czy rozwiązanie kwestii żydowskiej polegające na wyjściu $z$ owej „ciasnej sfery” jest w ogóle możliwe. Kwalifikuje je raczej do świata złudzeń i mrzonek, i łączy z mało prawdopodobnym scenariuszem wydarzeń.

Zgodnie $\mathrm{z}$ zapowiedzia, odwołajmy się teraz do recenzji, jakie ukazały się po opublikowaniu książki $Z$ ciasnej sfery. Na temat powieści jako pierwszy pisał wymieniony już Sowiński w 1878 roku:

„Gazeta Lubelska” 1877, nr 121, z 24 X, s. 1.

Ludomir Ludwik Szczerbowicz-Wieczór (1842-1899) - studia uniwersyteckie ukończył w Moskwie (1864), następnie mianowany nauczycielem gimnazjum w Kielcach, w r. 1867 był nauczycielem progimnazjum w Częstochowie, od r. 1872 - w gimnazjum w Warszawie, a od r. 1877 w Płocku. Jego najważniejsze prace to: Polemiczna kronika czasopism (1872-1874), Skorowidz błędów językowych (1877), Kobiety historyczne (1883-1887) oraz Kalectwa mowy (1884), Studia z literatury polskiej (1877-1878). Zob. Szczerbowicz-Wieczór Ludomir Ludwik. Hasło w: S. O r g e 1b r and, Encyklopedia powszechna. T. 14. Warszawa 1903, s. 241. 
Jeśli pierś czyja zatruta wyziewami kłamstwa i brudów, wydobywającymi się z laboratoriów literatury fabrycznej sui generis, zapragnie odetchnąć świeżym powietrzem prawdy i piękna, wonią balsamiczną wrażeń uszlachetniających, uczuć wzniosłych i szczerych, uzdrawiającej i trzeźwej myśli, niech weźmie do rąk prześliczny utwór pani Meyersonowej, Izraelitki z Lublina, noszący tytuł Z ciasnej sfery a fala tego tchu ożywczego wpłynie w pierś czytelnika nie ze świata odwzorowanego w powieści, świata zaprawdę smutnego i niezdrowego, ale $z$ serca samej autorki, przepełnionego głębokim współczuciem dla współwyznawców swoich i gorącą miłością kraju rodzinnego. [S 42]

Takim entuzjastycznym wstępem, wyrażonym jednym zdaniem (!), rozpoczyna Sowiński swoją recenzję i kontynuuje ją w podobnym stylu. Zaraz bowiem dopowiada, że lektura powieści przynosi nie tylko korzyści moralne i „orzeźwiające krople otuchy”, ale także „artystyczną [...] rozkosz” spowodowaną „dziwną harmonią" i „zdumiewająca prostotą i oszczędnością środków”; zachwyt recenzenta wywołują: „,ciepło serdeczne obok wstrzemięźliwości lirycznej” oraz „swojski charakter krajobrazu i zdarzeń wystawionych w powieści” (S 42). Przypomina także wydanego 10 lat wcześniej Dawida, po którym już można było się spodziewać znakomitej kontynuacji literackiej. Recenzent sygnalizuje też na początku, że „osnowa powieści” jest „niepospolicie zajmującą i dramatyczną” i jednocześnie bardzo realistyczną, bo „wziętą [...] z życia” (S 42). Następnie Sowiński koncentruje się na postaciach, rozpoczynając charakterystykę reb Lejba, którego:

Niezachwiana i ślepa wiara, surowa patriarchalna powaga, prawość niezłomna, a zarazem fanatyczna wyłączność pod względem przekonań wyznaniowych - odznaczają każdy czyn jego. [S 42]

\section{Krytyk pisze:}

Przypomina on [tj. reb Lejb] postać wojewody z Powrotu do gniazda Kraszewskiego. $Z$ drogi, którą raz uznał za prosta, czy w dostatku, czy w nędzy, nie zbacza już do grobu ani na prawo, ani na lewo. [S 42]

Nic dziwnego, że w osobie zięcia Eliasza widzi Sowiński niebezpieczeństwo, które „rozszerzyć może gangrenę na całe prawowierne ciało żydowskie” (S 42).

Historię innego „wybitnego” bohatera powieści $Z$ ciasnej sfery, Akiwy, w młodości będacego pilnym, a później osamotnionym w swych dążeniach do zgłębiania wiedzy i wykluczonym ze środowiska talmudystą, Sowiński tak prezentuje:

Samotny uczony, pozbawiony wszelkiego pola działalności, na którym by wiedzę swoją mógł zużytkować, odgrodzony od otoczenia całą swoją wyższością intelektualną, napiętnowany mianem grzesznika (posze), odwrócony od jasnej strony życia, od miłości rodziny i współbraci, tracił powoli cudowną energię dążeń i tę wartość etyczną, która z niej wypływa; zewsząd go obsiadły potworne cienie zwątpienia, sobkowstwa i cynizmu. [S 42]

Krytyk poświęca też uwagę bohaterkom powieści, wyraziście pokazując zmiany zachodzące w ich postawach. Blima, małżonka Lejba, tradycyjnie - żona i matka, która ,jest sobie prostą kobietą, wielbiącą głowę rodziny, rozmiłowaną namiętnie najprzód w córce, a potem we wnuczce i umierająca w chwili majątkowej ruiny" (S 43), nie może przeżyć utraty majątku i świetności, bo to one stanowią jej świat. Recenzent kreśli również portret córki - Belli, typowej żydowskiej dziewczyny, we wszystkim podporządkowanej rodzicom oraz mężowi, umierającej „Z tajemnica miłości swojej do męża, z którym ją rozłączyły wyznaniowe uprzedzenia rodzica" (S 43). Z największym jednak upodobaniem, jak pisze Sowiński, Meyersonowa 
prezentuje „postać Speranzy, córki Belli, ideał współczesnej dziewicy izraelskiej, którą wyrywa $z$ ciasnej sfery wyższe pojęcie o obowiązkach kobiety, myśl ofiary i pracy, oraz miłość gorąca do szlachetnego człowieka” (S 43).

Podsumowując swoje rozważania, recenzent podkreśla znaczenie słów zamykających utwór, zawierających apel do czytelników, aby powtórzyć je za Meyersonową, i jak się można domyślać, stanowiących dla Sowińskiego najbardziej wymowny fragment w „ślicznej jej powieści” (S 43):

Bracia! ilu nas jest, podajmy sobie ręce, a zmurszała warownia runie bezpowrotnie, wszystkie dzieci naszej ziemi odetchną czystym powietrzem pól ojczystych, i c i a s na sfer a rozprzestrzeni się w krag wielki i świetlany, obejmujący cały obszar interesów kraju i ludzkości! [MZ 214]

Drugim z kolei tekstem o powieści Meyersonowej, jaki można odnaleźć w ówczesnej prasie, jest wymieniony tu obszerny artykuł z „Bluszczu”, napisany przez wspomnianego już Krzemińskiego. Autor ten traktuje określenie „ciasna sfera” jak hasło, które spotykamy niemalże wszędzie, stąd bierze się jego niezwykła popularność i moc, ale także siła napędzająca ludzkość do zmian i postępu.

I ogrom, i pył drobny pod jednym rozwijają się prawem: zarówno potrzebują rozsuwać szranki dotychczasowego bytu, piąć się coraz wyżej, ciągle wzbogacać, potężnieć, z krępujących więzów do swobody, z ciemności do światła przedzierać. [K 357]

Wychodzenie „Z ciasnej sfery” to zatem powszechne prawo każdego człowieka. Postęp na świecie jest do zrealizowania właśnie dzięki nieustannemu poszerzaniu „ciasnej sfery”, uświadamianiu sobie wszelkich ograniczeń i pozbywaniu się ich. Recenzent przyznaje, że w ówczesnych polskich realiach taką najciaśniejszą sferę tworzą Żydzi, których już w przeszłości próbowano niejednokrotnie połączyć z całym społeczeństwem za pomocą ekonomiczno-socjalnych środków prawodawczych. Niestety, takie działanie „mechaniczne” (według określenia autora), nie mogło zakończyć się sukcesem. Potrzebne jest bowiem działanie „organiczne”, którym ,jedynie tylko oświata być może” (K 357). Tak Krzemiński precyzuje swoje stanowisko:

Oświata sama jedna tylko wyprowadzić zdoła tłumy ciemne z egipskiej ziemi niewoli, która jest dla nich ślepa, bezmyślna, prawom życia dzisiejszej ludzkości, prawom życia danego społeczeństwa wręcz przeciwstawiająca się tradycja. Oświata to nowy Mojżesz dla Żydów XIX wieku, to Mesjasz przez nich oczekiwany. Oświata rozstrzyguje wiele sporów, zaradzi wielu nędzom, urządzi wiele stosunków. Oświata zburzy warownie przesądu i rzuci w dusze anielskie ziarno obywatelstwa. Od oświaty życie społeczne Izraelitów rozpocząć się musi. [K 357]

Na zakończenie recenzent zajmuje się sprawą języka powieści i przyznaje, że, niestety, ta strona utworu pozostawia wiele do życzenia. Krzemiński przytacza przykłady, które mają zilustrować niedoskonałości języka Meyersonowej (np. zamiast „pukał” jest „zapukał” 〈MZ 3〉; zamiast „gołąbko moja” jest „gołąbku mój”〈MZ 14〉; zamiast „nie należę do rzędu ludzi pobożnych” jest „nie należę do ludzi pobożnych” 〈MZ 26〉). Większość z tych uchybień, które wytyka Krzemiński, w obecnej sytuacji liberalizacji języka trudno uznać za błędy.

Trzecią w kolejności publikacją związaną z tekstem Meyersonowej jest wspomniany już tu artykuł Szczerbowicza-Wieczora. Niestety, recenzent nie podziela rozwiązania, jakie podsunęła Meyersonowa, aby, „nie tykając ortodoksji żydowskiej, można by ją z ciasnej sfery pchnąć na szerszą [drogę [...]”, jednocześnie Szczerbo- 
wicz uznaje za bezzasadne żądanie takiej wskazówki od autorki, bo przecież „trudno dziś o arcydzieła genialne [...]” (Sz 197). Utwór stałby się wybitny, ,gdyby podawał skuteczne środki rozstrzygnięcia trudnej tej kwestii, nie łatwiejszej od kwadratury koła" (Sz 197). Najwyraźniej krytyk z góry zakłada, że nie jest możliwe wyjście Żydów z „ciasnej sfery”, i do takiej koncepcji dopasowuje swoją argumentację. Tekst ten stanowi wymowny przykład recenzji tendencyjnej, w której postawiona na początku określona teza zostaje udowodniona według strategii przyjętej z góry i za pomoca odpowiednio sformułowanych argumentów.

Szczerbowicz-Wieczór przeprowadza także charakterystykę wybranych postaci powieściowych. Jako pierwszego opisuje Eliasza, który „Z "ciasnej sfery" wychodzi niby na szersza [...]" (podkreśl. A. J.-P.), wyrwawszy się spod ortodoksyjnych reguł swego teścia Lejba, następnie „wchodzi na drogę praktyczna [...]” i jako legionista walczy „za obca sprawę Napoleona” (Sz 197). To wychodzenie „na niby” umotywowane zostaje budzeniem się uczuć obywatelskich, ale według recenzenta czytelnik „myślący” (!) chciałby czegoś więcej, a „mianowicie poznać cały przebieg rewolucji umysłowej i psychicznej, która z Żyda uczyniła obywatela [...]". Szczerbowicz konstatuje więc, że w postaci Eliasza „daje nam autorka coś, ale daje za mało" (Sz 197). Podobny niedosyt odczuwa recenzent oceniając Akiwę, pisze bowiem: „wyłamywanie się spod ciasnej ortodoksji żydowskiej i jej wszechpotężnego kierunku do dobrego nie prowadzi" (Sz 197). W konstrukcji owej postaci Szczerbowicz dostrzega błędy, które pozostają „w dziwnej sprzeczności z założeniem autorki”, jak choćby to, iż „Akiwa ginie za to, że usiłował wydobyć się z "ciasnej sfery“ [...]” (Sz 197). $Z$ tego wywodu wynika, iż przedstawiciele tzw. emancypowanych Żydów „nie udali się" Meyersonowej, potwierdzają oni natomiast założenie recenzenta, że proces emancypacji (rozumiany tu jako asymilacja czy polonizacja ${ }^{28}$ ) skazany jest z góry na niepowodzenie.

Charakterystykę drugiej grupy bohaterów powieści - tzw. ciasnej ortodoksyjnej sfery (według określenia autora), Szczerbowicz rozpoczyna od „Wybitnego i zupełnego [jej] przedstawiciela” (Sz 197) - reb Lejba, który, zdaniem krytyka, jest przede wszystkim Żydem, dopiero potem zaś człowiekiem i obywatelem. To żydostwo stanowi sens i sedno jego życia, wszelkie działania, a nawet uczucia, zależą od zasad i prawideł religijnych.

Dla właściwego rozumienia i oceniania przemian, jakie były udziałem społeczności żydowskiej w w. XIX, warto przywołać bardziej precyzyjne ustalenia dotyczące definiowania procesu asymilacji i jego wielowymiarowego charakteru. W przypadku „projektu” Meyersonowej (który przypieczętowała, wyrażając aprobatę dla Pierwszego Walnego Zjazdu Zjednoczenia Polaków Wyznania Mojżeszowego Wszystkich Ziem Polskich w 1919 r.) chodziło o ukształtowanie Polaka wyznania mojżeszowego. Asymilacja zatem dotyczyła akulturacji, integracji i emancypacji, bez zmiany religii, ale $\mathrm{z}$ odrzuceniem ortodoksji. Zob. też T. M. En d elm a n, Assimilation. Hasło w: The YIVO Encyclopedia of Jews in Eastern Europe. Ed. G. D. H un d ert. New Haven, Con., 2008. Cyt. za: A. J a g o d z iń s k a, Pomiędzy. Akulturacja Żydów Warszawy w drugiej połowie XIX wieku. Wrocław 2008, s. 11: „pojęciowo [asymilacja] obejmuje cztery analitycznie odrębne przemiany (i często jest mylnie z nimi utożsamiana), jakie zachodziły w zachowaniu i statusie Żydów XIX i XX wieku: akulturację (przyjęcie kulturowych i społecznych zwyczajów dominującej grupy nie-Żydów), integrację (wejście Żydów do nieżydowskich kręgów społecznych i sfer działalności), emancypację (otrzymanie praw i przywilejów, jakie posiadali obywatele/poddani z podobnej socjoekonomicznie warstwy) i sekularyzację (odrzucenie religijnych wierzeń oraz obowiązków i praktyk z nich wypływających)”. 
W dalszej części recenzji pojawiają się pochwały, dotyczące najpierw sposobu przedstawiania świata: „bardzo zajmująco, dosadnie i z niekłamaną prawdą życiową”, i choć Szczerbowicz-Wieczór wtrąca, że „Autorka wystawiła nam [...] świat żydowski odrębnym, zamkniętym w sobie”, to jednak „Dzieje dwukrotnego oblężenia tego miasta [tj. Gdańska] opisane są przez autorkę wybornie i z całą tragicznością" (Sz 197). Na pochwałę zasługuje również pokazanie uczciwości i rzetelności Lejba w stosunku do Borzęckich, których skarb rodowy Żyd chronił i ukrywał, nie ruszając go nawet wtedy, gdy sam znajdował się w sytuacji bez wyjścia. Ale zaraz pojawia się zarzut, iż dobre stosunki polsko-żydowskie zostały przedstawione tylko na jednym przykładzie relacji: Borzęcki-Lejb. Dalej dowiadujemy się, że „O typach kobiecych nie ma co mówić wobec upośledzenia kobiety u Żydów”; Szczerbowicz wymienia tylko Speranzę, która mimo „niezaprzeczalnych zalet” jest „typem niewykończonym, niewyrobionym" (Sz 197). Autor recenzji prezentuje ewidentnie nieprzychylny stosunek do Żydów, wynikający niejednokrotnie ze słabej znajomości ich religii, zwyczajów i tradycji.

Mimo tych uwag krytycznych konkluzja wydaje się pozytywna, choć może niezbyt przekonująca - książkę Meyersonowej „warto [...] przeczytać i nad nią się zastanowič”; w przedostatnim zdaniu pada też stwierdzenie, że to „powieść tendencyjna, a choć kwestii nie rozwiązuje, tendencja jest dobra” (Sz 197). Ta lakoniczna klasyfikacja nie została ani wyjaśniona, ani rozwinięta. Autor recenzji nie pisze, na jakiej podstawie zaliczył utwór do gatunku powieści tendencyjnych. Może miały o tym świadczyć wszystkie wcześniejsze uwagi? Niestety, one nie wskazują na cechy i wyznaczniki, o których dałoby się powiedzieć bez wątpliwości, iż dotyczą tego gatunku ${ }^{29}$.

Wracając do przeglądu recenzji prasowych, warto przyjrzeć się Lubelszczyźnie, okazuje się bowiem, że i tu odnaleźć dałoby się artykuły dotyczące dokonań Meyersonowej, nie tylko krótkie i lakoniczne notki informacyjne. Otóż w „Kalendarzu Lubelskim na Rok Zwyczajny 1879" Jakub Goldszmit dział literacki zamyka „wzmianką o pracy lublinianki, jedynej w swoim rodzaju, bo wprowadzającej nas do sfer nieznanych prawie szerszemu kołu czytającego ogółu”30. Przedmiotem za-

29 Warto w tym miejscu odnieść się do terminu „powieść tendencyjna” i zasygnalizować rozmaite sposoby jej definiowania, poczynając od zupełnie prymarnego rozróżnienia tendencji jako jednoznacznej myśli o rysie szczegółowym oraz idei mającej charakter ogólny i niejednoznaczny, po ujęcie w perspektywie historycznej i typologicznej. Zob. więcej na ten temat: T. Ci eśli kow s ka, Problem tendencyjnej powieści pozytywizmu. „Prace Polonistyczne” 16 (1960). Na dwoistość tego pojęcia zwracała uwagę S. Skw a r c zy ń s k a (Wstęp do naukio literaturze. T. 1, Warszawa 1954, s. 290), wskazując, że o tendencyjności w literaturze można mówić w kontekście występowania w różnych epokach historycznych, a także ,jako o zjawisku specyficznie określonym w okresie pozytywizmu, w którym słowo "tendencja" ma funkcję terminu w nauce o literaturze". Dla S. R. S u l e i m a n (Authoritarian Fictions. The Ideological Novel as a Literary Genre. New York 1983, s. 56) z kolei podstawową cechą dystynktywna powieści tendencyjnej jest szczególna relacja z odbiorca, polegająca na określeniu sposobu czytania tekstu. Trzecim elementem wyróżniającym ten typ utworu (oprócz oparcia świata przedstawionego na dualistycznym systemie wartości i istnienia apelu skierowanego do odbiorcy) jest „doktrynalny intertekst”, wymuszający prawidłowe odczytanie powieści. Zob. też W. To ma si k, Polska powieść tendencyjna 1949-1955. Wrocław 1988 , s. $18-20$.

30 J. Gold szmit, Rachunki za rok ubiegty 1878. (Kronika lubelska). „Kalendarz Lubelski na Rok Zwyczajny 1879", s. 68. 
interesowania publicysty jest powieść Z ciasnej sfery, w której „autorka wprowadza nas w krąg familijnego życia Żydów, zaznajamia z życiem ich owym rodzinnym, patriarchalnym, ujawnia dodatnie, odsłania ujemne jego strony"31. Goldszmit zwraca uwagę na fakt, iż obok fabuły powieściowej i charakterystyki „ciasnej sfery”, które stanowią właściwą kanwę opowieści, czytelnik znajduje opisy zdarzeń historycznych. One są dowodem na doskonała znajomość historii Polski, faktów i postaci przez Meyersonowa, ale także ich wpływu na losy ojczyzny. Według publicysty szczególnie podkreślić należy też styl i język powieści oraz silnie przemawiająca do czytelnika miłość do kraju, hołd dla bohaterów narodowych, hasła postępu, zarówno w myśli, jak i w czynie. Goldszmit swoją recenzję kończy następująco:

Przyjdzie czas, kiedy zmurszała warownia (przesądów społecznych) runie bezpowrotnie, wszystkie dzieci naszej ziemi odetchną czystym powietrzem pól ojczystych, i „ciasna sfera” rozprzestrzeni się w krag wielki i świetlany, obejmujący cały obszar interesów kraju i ludzkości - oto dewiza, oto godło autorki. Powieść tę polecamy bacznej uwadze tych zwłaszcza czytelników, którzy lubuja się w prześlicznych powieściach z życia żydowskiego hojną dłonią przez panią Elizę Orzeszkową czerpanych, a w czasopismach naszych przez zdolną tę bojowniczkę emancypacji bezprzestannie ogłaszanych. Pracy jednak pani Mejersonowej bezwarunkowo pierwszeństwo przyznać musimy, choćby z tego już względu, że autorka, kreśląc szkice i charaktery swych współwyznawców, czerpiąc już tym samym materiał do szkiców i scen owych z pierwszego źródła, rozważniej i dojrzalej o przedmiocie traktowanym przez siebie sądzić może, $\mathrm{w}$ żadnym razie nie uwodząc się zbytnio w sądach swych ani zbyteczną surowością, ani też skrajną pobłażliwością ${ }^{32}$.

Na zakończenie tego przeglądu recenzji dotyczacych powieści Meyersonowej chciałabym na chwilę zatrzymać się przy tekście obszernego studium Walerii Marrené, drukowanym w „Tygodniku Ilustrowanym” w 1879 roku, które porusza kwestię żydowską w powieści ówczesnej, we wprowadzeniu zaś analizuje przyczyny konfliktów między społecznością polską a mieszkańcami pochodzenia żydowskiego ${ }^{33}$. Marrené rozpoczyna swoje rozważania od spraw ogólnych, dotyczących specyfiki wieku XIX, nieustannie odbywających się dyskusji politycznych, ideologicznych, socjalnych i rozstrzygnięcia niezliczonych kwestii wynikających ze zmieniajacych się warunków życia społeczeństwa. Ich rozmaite przejawy znajdują rezonans w literaturze, a szczególnie w powieści, która według Kraszewskiego ma być zwierciadłem społecznym ${ }^{34}$. Marrené jednak informuje, iż do badania wybrała tylko „utwory piór znakomitych" 35 , bo tylko takie zasługują na uwagę. Przygląda się powieściom trzech literatur europejskich (francuskiej, niemieckiej i angielskiej) oraz zestawia je z utworami polskimi, dlatego że:

nigdzie kwestia judaizmu nie przybrała tak wielkiego natężenia, a zatem przedstawia się tak wybitnie,

31

Ibidem.

Ibidem, s. 69.

W. Marrené, Kwestia żydowska w powieści współczesnej. Studium. [Cz. 1]. „Tygodnik Ilustrowany” 1879, nr 194, z 13 IX.

Waleria Marre né, primo voto Morzkowska, de domo Mallet de Grandville-Malletski (1832-1903) polska pisarka, publicystka, krytyczka literacka i feministka okresu pozytywizmu. Jest autorką ponad 20 powieści, a także wielu artykułów publicystycznych i literackich oraz Historii sztuki. Zob. Marrené Waleria. Hasło w: Or gelbrand, op. cit., t. 10 (1901), s. 1.

Marrené, op. cit., s. 165-166.

Ibidem, s. 166. 
gdyż w żadnym kraju, stojącym jak nasz na wyższym stopniu cywilizacji, liczebny stosunek Izraelitów nie jest tak wielki ${ }^{36}$.

Badaczka wybiera do analizy trzy powieści Orzeszkowej (Pan Graba, Eli Makower i Meir Ezofowicz) oraz ostatnią powieść Meyersonowej (Z ciasnej sfery). Wniosek, jaki formułuje po omówieniu utworów Orzeszkowej, wskazuje, że wszelkie, mniej lub bardziej udane, próby rozwiązania kwestii żydowskiej „z zewnątrz”, nie mogą spełnić pokładanych w nich nadziei. Sa zawsze „obce”, nabierają, siła rzeczy, charakteru wymuszania czy narzucania pewnych rozwiązań. Potrzebny i wręcz nieodzowny wydaje się impuls „od wewnątrz”, płynący od samych zainteresowanych, gdyż wszelkie projekty „obcych” skazane są z góry na niepowodzenie. Dlatego Marrené z ogromną i nieukrywaną satysfakcją podkreśla przejawy tego rodzaju działań. Pisze bowiem:

Takim ciekawym, pouczającym i pocieszającym objawem są dla nas powieści pani Malwiny Meyersonowej, a szczególnie ostatnia $\mathrm{z}$ nich, zatytułowana $Z$ ciasnej sfery ${ }^{37}$.

Publicystka podkreśla zalety powieści: po pierwsze, osadzenie na tle historycznym, po drugie, wykorzystanie „papierów i podań familijnych”38, co niezwykle uwiarygodnia i postaci, i przebieg zdarzeń. Wyjście „z ciasnej sfery”, zetknięcie się $z$ innym światem powoduje, iż przesądy ustępują, bohaterowie w konfrontacji z faktami muszą pogodzić się z nieuchronną koleją historii. Marrené zauważa też, że w „ciasnej sferze”, w której „autorka umieściła widownię swojej powieści”, nie ma takich reformatorów, jak Meir Ezofowicz Orzeszkowej, u Meyersonowej ów „Żywioł buntowniczy przeniesiony [...]” zostaje do harmonijnie funkcjonującego świata „ciasnej sfery” z zewnątrz ${ }^{39}$. Reformatorem jest zięć Lejby, Eliasz, który wychowany w mniej hermetycznej rzeczywistości, nie może nagiąc się do surowych zasad obowiązujących w domu Gwira. Marrené tłumaczy, iż Eliasz w porównaniu z Meirem to postać bardziej przekonująca, wciela bowiem „zmysł praktyczny Izraelitów. Jest on mniej podniosły od Meira, ale choć powszedniejszy, równie, a może nawet bardziej sympatyczny od niego, co najważniejsze zaś - bardziej zrozumiały" ${ }^{40}$.

Autorka studium uważa, że „Niepodobna $z$ większą czcią odmalować przeszłości, gdy ta minęła niepowrotnie”; sposób, w jaki czyni to Meyersonowa, świadczy o wielkiej doniosłości jej pracy i „określa tak wybitnie stanowisko, jakie w piśmiennictwie naszym zajęła" ${ }^{1}$. Tak wysoka ocena powieści $Z$ ciasnej sfery zostaje jeszcze wzmocniona opinią, iż „nie ma w niej najmniejszej tendencyjności [...]”, problemy społeczne bowiem „przychodza jej [tj. Meyersonowej] pod pióro mimochodem niejako; nie one wywołuja akcyja, ale, przeciwnie, sa przez nią wywołane" ${ }^{42}$. Dowodem na słuszność tej tezy ma być „wielka logiczność wypadków, nie naginających się

Ibidem.

W. Marrené, Kwestia żydowska $w$ powieści współczesnej. Studium. [Cz. 2]. „Tygodnik Ilustrowany" 1879, nr 201, z 31 X, s. 284.

Ibidem.

Ibidem.

W. Marrené, Kwestia żydowska w powieści współczesnej. Studium. [Cz. 3]. „Tygodnik Ilustrowany" 1879, nr 202, z 8 XI, s. 300.

Ibidem.

Ibidem. 
bynajmniej do myśli głównej, ale płynących swoim biegiem"; w powieści obok wątku nadrzędnego rozwijają się wątki poboczne, „tak jak to bywa w życiu, które jest ciągłą doświadczalną nauką" ${ }^{3}$. Ta wielowątkowość zasługuje na szczególną uwagę, gdyż Meyersonowa pokazuje nie tylko konflikty między swoimi współwyznawcami, lecz także stosunek Żydów do chrześcijan, ze stanowiska typowego dla osoby wyznania mojżeszowego, a nie, jak to było dotychczas - ze stanowiska pisarzy chrześcijańskich. Marrené podkreśla ten fakt $\mathrm{z}$ dużym naciskiem:

A pogląd to tym ciekawszy, że autorka traktuje swój przedmiot z dziwną obiektywnością, że jest ona prostym historiografem faktów. Ale fakta mają swoję wymowę, stokroć donioślejszą od najwymowniejszych tyrad ${ }^{44}$.

Wspomniałam we wstępie, iż Meyersonowa przełożyła na polski dwa utwory niemieckojęzyczne. Ich publikacje zbiegają się z tekstami autorskimi pisarki, jak wiemy, drukowanymi najpierw w odcinkach w „Izraelicie”, a potem wydawanymi jako samodzielne książki. Prawie równolegle z Dawidem 1 VIII 1868 „Kurier Lubelski” (nr 73) ogłosił opowiadanie Heinricha Zschokkego ${ }^{45}$ Der zerbrochene Krug, w przekładzie Meyersonowej zatytułowane Marietta, czyli sttuczony dzban ${ }^{46}$. Tekst oryginalny powstał w wyniku konkursu literackiego na najlepszy utwór inspirowany miedziorytem przedstawiającym scenę sądu nad winnym rozbitego dzbana ${ }^{47}$ stanowiącym dla trójki pisarzy (Ludwiga F. A. Wielanda ${ }^{48}$ i Heinricha von Kleista oraz Zschokkego) źródło natchnienia artystycznego. Powstały zatem trzy odrębne teksty: opowiadanie Zschokkego, komedia Kleista i satyra Wielanda. Utwór dramatyczny zdobył nie tylko pierwsze miejsce w rywalizacji trzech autorów, ale także największą popularność ${ }^{49}$. Opowiadanie, które przetłumaczyła Meyersonowa, to pełna zaskakujących wydarzeń historia miłości Marietty i Collina. Mimo wielu niesprzyjających okoliczności (m.in. pozwania do sądu ukochanego dziewczyny oraz oskarżenia go o zniszczenie dzbana) - znikają przeszkody stojące młodym na drodze do szczęścia, a wszystkie oszustwa wychodzą na jaw, zwyciężają prawda i szczere uczucie $^{50}$.

43 Ibidem.

44 Ibidem.

45 Johann Heinrich Daniel Zs ch o k k e (1771-1848) - niemiecki pisarz i pedagog epoki oświecenia, wolnomularz, wykładowca Uniwersytetu Viadrina we Frankfurcie nad Odrą. Był jednym z najbardziej poczytnych i wpływowych niemieckich autorów XIX wieku. Najważniejsze jego utwory to: Hans Dampf in allen Gassen (1814), Das Goldmacherdorf (1817), Das Abenteuer in der Neujahrsnacht (1818), Der Flüchtling im Jura (1822) i Der Freihof von Aarau (1823). Informacja pochodzi z Kartoteki osobowej Stanisława Bubienia (Wojewódzka Bibl. Publiczna im. Hieronima Łopacińskiego, k. 1181-1190).

Mowa o miedziorycie francuskiego artysty J. J. Le V e a u Le Juge ou la cruche cassée (Sędzia, albo rozbity dzban), wykonanym według obrazu Ph.-L. Debucourta z 1782 roku.

Ludwig Friedrich August W i e la n d (1777-1819) - niemiecki poeta i wydawca. Do najważniejszych jego prac zaliczają się: Erzählungen und Dialogen. T. 1: Das Fest der Liebe. Dialogen (1803), Auswahl denkwürdiger Briefe (1815), Bemerkungen gegen die Schrift des Geheimenrath Schmalz zu Berlin über politische Vereine (1815) oraz Giebt es gegenwärtig in Deutschland eine revolutionäre Partei und wie kann man wider Willen eine machen? (1819).

Chodzi o Rozbity dzban H. Kle ista (Przeł. J. Mirski. Oprac. M. Urbanowicz. Wrocław 1957. BN II 109).

Zob. J. H. D. Zo s chkke, The Broken Cup. Transl. G. Parke. Copyright 1891, by The Current 
Drugi przekład autorstwa Meyersonowej, o znacznie większej objętości, to wspomniana już powieść Louise von François ${ }^{51}$ Ostatnia z Rekenburgów, drukowana w „Tygodniku Ilustrowanym” w dodatku od numeru 54 (z 6 I 1877) do numeru 65 (z 24 III 1877), czyli w kolejnych 12 numerach. Utwór ten stanowi swoistą sagę rodzinną Rekenburgów, opowiadającą historię zarówno tzw. linii czarnej, reprezentowanej przez bogatą Eberhardynę, panią na zamku rekenburskim, jak i linii białej - jej przedstawicielami są Adelajda i Eberhard oraz ich córka Hardyna. W kontekście dokonań społecznych Meyersonowej, jej przekonań i idei, którym była wierna przez całe życie, można postawić tezę, że wybór takiego utworu do tłumaczenia to nie dzieło przypadku. Powieść von François stanowi swoistą wykładnię postawy tłumaczki, wyjaśnia i dopełnia jej podejście zarówno do spraw wychowania, edukacji, jak i do aksjologii czy etyki. Główna bohaterka, Hardyna, reprezentuje wszystkie te cechy, które według Meyersonowej świadczyły o randze człowieka, a dokładniej - o kobiecie wyemancypowanej, znającej swoją wartość, odważnej, silnej, odpowiedzialnej, nie poddającej się przeciwnościom, ale jednocześnie szanującej tradycję, chroniącej pamięć przodków, przestrzegającej odwiecznych zasad i reguł.

Przywracanie pamięci o dokonaniach Malwiny Meyersonowej chciałabym zakończyć przywołaniem słów odbiorców powieści $Z$ ciasnej sfery i Dawida. Słowa te są tak samo ważne dla recepcji twórczości pisarki, jak opinie i komentarze profesjonalnych recenzentów. Wskazują bowiem na znaczenie jej prozy dla tzw. zwykłych odbiorców. Oddźwięk czytelniczy po zakończeniu druku odcinków powieści $Z$ ciasnej sfery w „Izraelicie” był niemal natychmiastowy. W numerze 16 z 1878 roku zamieszczono taki komentarz na jej temat: „ogół współwyznawców naszych żywo się nią interesował [...]"52. Po pierwsze, dlatego wzbudziła ciekawość, że napisała ją kobieta, a po drugie, że ten utwór opowiadający o życiu żydowskim „zaliczyć by można [...] do nader rzadkich zjawisk"53. Ewidentne tego potwierdzenie stanowiła opinia czytelniczki „Izraelity”, której list do redakcji przytaczam w całości z nadzieją, iż próba ocalenia pamięci o pierwszej lubelskiej Żydówce piszącej po polsku została podjęta:

Z prawdziwym zajęciem czytuję tę powieść - rzekła do nas pewna pani, gdyśmy się o jej zdanie spytali. - Autorka poruszyła tu jednę z najważniejszych kwestyj, odnoszących się do zwyczajów zachowawczych warstw izraelskich, a mianowicie - kwestię wczesnego zawierania małżeństw i zgubnych stąd

Literature Publishing Company, [on-line:] http://www.gutenberg.org/ebooks/search/?query =Heinrich+Zschokke oraz http://www.gutenberg.org/files/23062/23062-h/23062-h.htm, (data dostępu: 7 VII 2017). Niestety, osiagalna jest tylko angielska wersja tego utworu Zoschkkego.

Marie Louise v on Fra nç o is (1817-1893) - niemiecka pisarka pochodząca z zamożnej rodziny. Najważniejsze utwory tej autorki to - powieści: Die letzte Reckenburgerin (1871), Frau Erdmuthens Zwillingssöhne (1873), Stufenjahre eines Glücklichen (1877), Der Katzenjunker (1879), zbiory opowiadań: Ausgewählte Novellen (1868), Erzählungen (1871), Hellstädt und andre Erzählungen (1874), Natur und Gnade, nebst andern Erzählungen (1875), Phosphorus Hollunder. Zu Füßen des Monarchen (1881), oraz komedia: Der Posten der Frau. Lustspiel in fünf Aufzügen (1881). Zob. też na stronie: http://gutenberg.spiegel.de/buch/die-letzte-reckenburgerin-1126/1 (data dostępu: 7 VII 2017).

52 „Izraelita” 1878, nr 16, z 17 IV, s. 124. 
wyników. Szczerze jestem wdzięczną autorce, że tak ważną rzecz za temat sobie obrała, a sądzę, że wiele osób tego samego, co i ja, jest zdania. Jakaż to szkoda, że tak mało jest u nas autorów powieści z życia żydowskiego! Chociaż sobie mężczyźni zawsze i wszędzie wyższość nad nami przypisuja, to jednak w tym razie nolens volens ustapić musza palmy pierwszeństwa płci słabszej, boć wszakże nie zaprzeczysz mi pan, iż pani Meyerson jest jedyną u nas autorką-Izraelitką. Pięknych tematów do powieści nie brak - brak tylko chęci i zamiłowania ${ }^{54}$.

\author{
Abstract \\ ANNA JEZIORKOWSKA-POLAKOWSKA The John Paul II Catholic University of Lublin \\ ORCID: 0000-0001-5265-563X
}

\title{
MALWINA MEYERSONOWA'S EMANCIPATION PROJECT \\ ON THE RECEPTION OF TWO NOVELS
}

The article describes the figure and literary output of Malwina Meyersonowa, the first Lublin woman writer of Jewish origin writing in Polish. The person beyond measure deserves attention. This woman of Lublin $19^{\text {th }}$ century intellectual elite, mother of a poetess Franciszka Arnsztajnowa and a philosopher Emil Meyerson, is an authoress of two novels in which she touches the problems of Jewish people contemporary life. It may be argued that in this respect she was a predecessor of Eliza Orzeszkowa's novels on the same topic. The sources of Meyersonowa's creativity, connected to the idea of assimilation, emancipation, and the Jewish struggle to escape from the centuries-old isolation, can be located in the Haskalah movement. Meyersonowa was also a translator; her two translations from the German have remained. Her patriotic and social activity as well as many a year actions aimed at propagating education among the Jewish society complete the woman writer's artistic achievements. 